\title{
Seasonal differences in function of the hypothalamic-hypophysial-ovarian axis in weaned primiparous sows*
}

\author{
J. D. Armstrong, J. H. Britt and N. M. Cox $\dagger$ \\ Department of Animal Science, Box 7621, North Carolina State University, Raleigh, \\ North Carolina 27695-7621, U.S.A.
}

\begin{abstract}
Summary. Primiparous sows were fed to appetite during lactations that occurred during winter or summer, and $11.4 \pm 0.4$ pigs per litter were weaned at $23.5 \pm 0 \cdot 1$ days of age. Sows were slaughtered at 0 or $72 \mathrm{~h}$ after weaning or blood samples were collected until $24 \mathrm{~h}$ after onset of oestrus. Sows that lactated during summer consumed less food and lost more $(P<0.05)$ weight, heartgirth and backfat than those that lactated during winter. Weaning-to-oestrus interval was greater $(P<0.05)$ in summer $(224 \pm 25 \mathrm{~h})$ than in winter $(93 \pm 13 \mathrm{~h})$. Content of GnRH in the hypothalamus and concentrations of LH in the anterior pituitary and serum were lower $(P<0.05)$ after weaning in summer than winter. The numbers of visible ovarian follicles $<5 \mathrm{~mm}$ in diameter at weaning were lower $(P<0.05)$ in summer than in winter. In contrast to LH, FSH concentration in serum was higher $(P<0 \cdot 10)$ in summer than winter, but FSH values in the anterior pituitary were lower $(P<0.05)$ in summer than in winter. Post-weaning patterns of secretion of oestradiol and follicular development differed between winter and summer. For example, in some sows weaned during the summer, transient surges of oestradiol occurred repeatedly during 0 to $280 \mathrm{~h}$ after weaning without provoking surges of $\mathrm{LH}$. These results indicate that the period of post-weaning anoestrus in summer is prolonged because of altered activity of the hypothalamicpituitary axis, possibly because of changes in sensitivity to the feedback of oestradiol. Lower feed intake during lactations that occur during summer may predispose the endocrine system to the aberrations.
\end{abstract}

\section{Introduction}

Normally, weaning results in increased synthesis of GnRH (Cox \& Britt, 1982c), increased synthesis and secretion of LH (Cox \& Britt, 1982c; Edwards \& Foxcroft, 1983), and increased follicular growth and secretion of oestradiol that culminates in oestrus and ovulation in sows within 3-10 days after weaning (Stevenson, Cox \& Britt, 1981; Cox \& Britt, 1982a; Edwards \& Foxcroft, 1983; Armstrong \& Britt, 1985).

Season affects duration of postweaning anoestrus because primiparous sows weaned during late summer or early fall have longer periods of postweaning anoestrus than do primiparous sows weaned during spring (Aumaitre, Dagorn, Legault \& Le Denmat, 1976; Hurtgen, Leman \& Crabo, 1980; Britt, Szarek \& Levis, 1983). This effect of season on postweaning anoestrus may be mediated through seasonal differences in food intake. Primiparous sows restricted in intake of energy and (or) protein during lactation had longer remating intervals than did unrestricted controls (Reese $e t$

*Reprint requests to Dr J. H. Britt.

$\nmid$ Present address: Department of Animal Science, Mississippi State University, Mississippi State, MS 39762, U.S.A. 
al., 1982; King \& Williams, 1984a, b). Season and intake of energy also may interact to affect remating intervals because restriction of intake of energy during lactation in the fall resulted in longer remating intervals than in the spring (Reese et al., 1982).

Prolonged anoestrus after weaning may be due to insufficient release of GnRH because hourly pulses of exogenous GnRH induced oestrus and ovulation in chronologically anoestrous, primiparous sows (Armstrong \& Britt, 1985). Chronic postweaning anoestrus may therefore be due to aberrations in the hypothalamus and (or) higher brain centres.

The objectives of this study were to determine whether seasonal differences in postweaning anoestrus of primiparous sows were associated with differences in intake of food during lactation and with postweaning differences in concentrations of hypothalamic GnRH, serum and anterior pituitary gonadotrophins and follicular development.

\section{Materials and Methods}

Experimental procedures. Landrace $\times$ Yorkshire primiparous sows that farrowed in March (winter, $N=17$ ) or August (summer, $N=19$ ), 1983, were used. Within season, sows were farrowed in a batch and lactated $23.5 \pm 0.1$ (mean \pm s.e.m.) days. Minimum temperature within the farrowing houses was maintained at about $20^{\circ} \mathrm{C}$ by providing supplementary heat; however, maximum temperature depended on outside temperature because outside air was used for ventilation. Lights in the farrowing houses were on during feeding and collection of blood samples, but length of photoperiod depended primarily on sunlight from windows on both sides of the houses. Litter sizes were equalized within 3 days of farrowing and the average litter size was $11.4 \pm 0.4$ pigs at weaning. During lactation, sows were fed to appetite (twice daily) a corn-soybean meal diet supplemented with vitamins and minerals according to NRC (1979) guidelines. Body weight, heartgirth circumference and backfat depth (measured ultrasonically $6 \mathrm{~cm}$ lateral to the midline at the last rib; Leanmeter, Renco Corp., Minneapolis, $\mathrm{MN}$ ) were recorded after farrowing and at the time of weaning.

Within season, sows were assigned at random to be slaughtered at weaning $(0 \mathrm{~h}$; winter, $\mathrm{N}=5$; summer, $\mathrm{N}=5$ ), $72 \mathrm{~h}$ after weaning (winter, $\mathrm{N}=6$; summer, $\mathrm{N}=4$ ) or a cannula was placed in the vena cava 1 day before weaning (winter, $N=6$; summer $N=10$ ). The cannulas were inserted through a 12-gauge needle under local anaesthesia, and were taped to the skin surface with elastic tape. Ovaries, anterior pituitaries and areas of brain encompassing the hypothalamus were obtained at slaughter. Numbers of visible ovarian surface follicles $<5 \mathrm{~mm}$ or $>5 \mathrm{~mm}$ in diameter were recorded. The interval from weaning to slaughter in the $0 \mathrm{~h}$ group was about $1 \mathrm{~h}$. Sows in the cannulated group were checked for oestrus with a mature boar twice daily beginning 1 day after weaning.

Hypothalamic tissue was dissected into two parts, medial basal hypothalamus (MBH) and stalk-median eminence (SME), as described by Cox \& Britt (1982c). The anterior pituitary was divided into two portions, the hypophysial portal area (HPA) and the remainder of the anterior pituitary. All tissues were stored in liquid nitrogen until subsequent analysis. Tissues for determination of GnRH concentration were homogenized in $3 \mathrm{ml} 2 \mathrm{~N}$-acetic acid (Estes, Padmanabhan \& Convey, 1977). After centrifugation at $1000 \mathrm{~g}$ for $30 \mathrm{~min}, 0.5 \mathrm{~N}$-sodium hydroxide was added to the supernatants until $\mathrm{pH}$ was neutralized $(\mathrm{pH}=7 \cdot 0)$. Supernatants were then frozen, freeze-dried, reconstituted with double-distilled water and stored at $-20^{\circ} \mathrm{C}$ until assayed for $\mathrm{GnRH}$. Anterior pituitaries were processed as previously described (Cox \& Britt, 1982c), except that pituitary extracts were diluted 1:9000 for LH and FSH assays.

In cannulated sows, blood samples were collected at 12 -h intervals from weaning until $24 \mathrm{~h}$ after the onset of oestrus or 10 days after weaning, whichever came first. Blood samples also were obtained at 15-min intervals (windows) for $3 \mathrm{~h}$ (summer) or $4 \mathrm{~h}$ (winter) at $0,24,48$ and $72 \mathrm{~h}$ after 
weaning. Samples obtained at 12 -h intervals were analysed for oestradiol-17 $\beta$ and, in selected instances, progesterone. All samples were analysed for LH. Alternate samples from windows obtained at 0 and $24 \mathrm{~h}$ after weaning were assayed for FSH.

Hormone assays. Serum and tissue LH, and progesterone concentrations were measured by radioimmunoassay procedures described by Stevenson et al. (1981). Average intra- and inter-assay coefficients of variations (CVs) were 11.9 and $16.2 \%$, respectively, for $7 \mathrm{LH}$ assays. Average recovery of progesterone was $90 \%$ and the average intra- and inter-assay CVs were 12.6 and $12.9 \%$, respectively. Assay sensitivities, defined as $90 \%$ of total binding, were 0.3 and $0.2 \mathrm{ng} / \mathrm{ml}$ for $\mathrm{LH}$ and progesterone, respectively.

Serum oestradiol-17 $\beta$ concentrations were assayed using antiserum provided by $\mathrm{Dr} N$. R. Mason (Mason \& March, 1975) as previously described (Cox \& Britt, 1982b). Intra- and interassay CVs for 6 assays were 13.8 and $14.9 \%$, respectively. Assay sensitivity, defined as above, was $8 \mathrm{pg} / \mathrm{ml}$.

Serum and tissue FSH were measured using anti- $\beta$-subunit FSH serum (USDA-10-1010) provided by Dr D. J. Bolt (Guthrie \& Bolt, 1983) with modifications as described by Esbenshade \& Britt (1985). Highly purified pig FSH (USDA-FSH-PP1) was iodinated by the Iodogen (Pierce Chem. Corp., Rockford, IL) method and pig FSH for standards (pFSH IA3-c2, 26.1 units/mg NIH-FSH-S1) was supplied by Dr R. J. Ryan and Dr R. J. Whitley (Mayo Clinic, Rochester, $\mathrm{MN}$ ). Intra- and inter-assay CVs for two assays were 12.3 and $17 \cdot 2 \%$, respectively; assay sensitivity was $0.4 \mathrm{ng} / \mathrm{ml}$.

Tissue GnRH was measured in tissue extracts $(200 \mu 1)$ using anti-GnRH serum (Miles Yeda, Rehovot, Israel) at a dilution of 1:80 000. Characteristics of this antiserum have been previously reported (Koch et al., 1973) with modifications validated in our laboratory (Cox \& Britt, 1982c). Synthetic GnRH (CEVA Labs, Overland Park, KS) was used for standards and was iodinated according to the procedure of Nett, Akbar, Niswender, Hedlund \& White (1973) except that ${ }^{125}$ I-labelled GnRH and free ${ }^{125} \mathrm{I}$ were separated using Sephadex LH-20-100. The sensitivity and intra-assay $\mathrm{CV}$ were $20 \mathrm{pg}$ and $11.6 \%$, respectively.

Statistical analyses. Least-squares analyses of variance were by general linear regression procedures of the Statistical Analysis System (SAS, 1982). Comparisons between summer and winter groups were made by Student's $t$ test (Steel \& Torrie, 1980). For least-squares analyses involving changes in body condition of sows as the dependent variable, the value of that particular measurement at farrowing, lactation length and number of pigs weaned were included as covariables. For analyses involving voluntary food intake as the dependent variable, location (farrowing house one or two) was included in the model. Covariables that did not contribute significantly $(P>0.05)$ in a particular analysis were omitted from subsequent analyses.

Analyses of variance of content of GnRH in the MBH, SME and HPA, concentrations of FSH and $\mathrm{LH}$ in the anterior pituitary, and number of small or large follicles were performed with season, hours after weaning and the two-way interaction as independent variables. Main effects and (or) interactions were omitted from models when not significant. GnRH, LH and FSH means were compared using Duncan's multiple range test (Steel \& Torrie, 1980). Due to heterogeneity of variance in content of GnRH amongst groups, data were transformed to log base 10 (Sokal \& Rohlf, 1969). Transformation of GnRH content in SME and MBH removed $(P>0 \cdot 1)$ heterogeneity of variance (Sokal \& Rohlf, 1969). All statistical analyses relating to GnRH content in $\mathrm{SME}$ and $\mathrm{MBH}$ were therefore performed on transformed data.

Concentration of $\mathrm{LH}$ and FSH in serum were analysed using split-plot analysis of variance for repeated measurements (Gill \& Hafs, 1971). Initial models for the analyses included season, sow within season, hours from weaning and the two-way interactions. Modifications of this model were used to evaluate data within a specific hour from weaning. The main effect of season was tested using the sow within-season mean square as the error term (Gill \& Hafs, 1971). 
Frequency of episodic release of $\mathrm{LH}$ (peaks/h) was determined by a subjective method (Stevenson \& Britt, 1979). Data were analysed for differences due to season, hour from weaning and the two-way interaction.

\section{Results}

Hours from weaning to oestrus were greater $(P<0.01)$ in summer $(224 \pm 25, \mathrm{~N}=9)$ than winter $(93 \pm 13, N=5$; Table 1) and ranges were $156-340$ and $48-130 \mathrm{~h}$ in summer and winter respectively. Sows that lactated during summer $(\mathrm{N}=19)$ consumed less energy and lost more weight, heartgirth and backfat during lactation than did sows that lactated during winter $(\mathrm{N}=17$; Table 1, $P<0.05)$. Average maximum daily temperatures of ambient air for ventilation of farrowing houses were $33.2 \pm 0.8$ and $16.9 \pm 1.0^{\circ} \mathrm{C}$ in summer and winter, respectively.

Table 1. Seasonal differences in weaning-to-oestrus interval and lactation traits of primiparous sows

\begin{tabular}{|c|c|c|c|}
\hline \multirow[b]{3}{*}{ Weaning to oestrus interval (h) } & \multicolumn{3}{|c|}{ Season } \\
\hline & \multicolumn{2}{|c|}{ Winter } & Summer \\
\hline & $93 \pm$ & $13^{*}$ & $224 \pm 25$ \\
\hline \multicolumn{4}{|l|}{ Lactation } \\
\hline Energy intake (kcal/day) & $14881 \pm$ & $532^{*}$ & $12275 \pm 544$ \\
\hline Weight change $(\mathrm{kg})$ & $-11.7 \pm$ & $5 \cdot 1^{*}$ & $-24 \cdot 0 \pm \quad 3 \cdot 2$ \\
\hline Heartgirth change $(\mathrm{cm})$ & $-16 \cdot 3 \pm$ & $0 \cdot 8^{*}$ & $-20 \cdot 3 \pm$ \\
\hline Backfat change (mm) & $-0.9 \pm$ & $0 \cdot 3^{*}$ & $-2 \cdot 1 \pm$ \\
\hline
\end{tabular}

Values are mean \pm s.e.m.

*Significantly different from summer values, $P<0.05$.

Concentrations of LH at $0(P<0.05)$ and $24 \mathrm{~h}(P<0.1)$ after weaning were greater in winter than summer, but levels were similar at 48 and $72 \mathrm{~h}$ after weaning (Table 2). Frequency of episodic release of $\mathrm{LH}$ (peaks $/ \mathrm{h}$ ) from 0 to $72 \mathrm{~h}$ after weaning was similar in sows weaned in winter and summer (Table 2). Average serum FSH concentration at weaning $(0 \mathrm{~h})$ tended to be greater $(P<0 \cdot 1)$ in summer than in winter, but FSH values $24 \mathrm{~h}$ after weaning were not different (Table 2).

Within each season, content of GnRH within specific tissues was similar at 0 and $72 \mathrm{~h}$ after weaning, so values were pooled. Content of $\mathrm{GnRH}$, in MBH $(P<0 \cdot 10)$, HPA $(P<0 \cdot 12)$ and SME $(P<0.001)$ was $2-4$ times greater for sows killed in winter than in summer (Fig. 1). Before logarithmic transformation, variance of content of GnRH in SME and $\mathrm{MBH}$ was greater in winter than in summer $(P<0.05)$.

Table 2. Serum FSH and $\mathrm{LH}$ concentrations and frequency of $\mathrm{LH}$ release in primiparous sows weaned in winter or summer

\begin{tabular}{|c|c|c|c|c|c|c|}
\hline \multirow{2}{*}{$\begin{array}{l}\text { Time from } \\
\text { weaning }(h)\end{array}$} & \multicolumn{2}{|c|}{$\mathrm{FSH}(\mathrm{ng} / \mathrm{ml})$} & \multicolumn{2}{|c|}{$\mathrm{LH}(\mathrm{ng} / \mathrm{ml})$} & \multicolumn{2}{|c|}{ LH (peaks/h) } \\
\hline & Winter & Summer & Winter & Summer & Winter & Summer \\
\hline 0 & $0.67 \pm 0.02^{a}$ & $0.93 \pm 0.01^{b}$ & $1.08 \pm 0.05^{\mathrm{c}}$ & $0.81 \pm 0.04^{d}$ & $0.61 \pm 0.12$ & $0.50 \pm 0.07$ \\
\hline 24 & $0.54 \pm 0.02$ & $0.79 \pm 0.01$ & $0.99 \pm 0.04^{\mathrm{a}}$ & $0.79 \pm 0.03^{\mathrm{b}}$ & $0.82 \pm 0.20$ & $0.68 \pm 0.08$ \\
\hline 48 & & & $0.83 \pm 0.05$ & $0.77 \pm 0.03$ & $0.66 \pm 0.13$ & $0.63 \pm 0.10$ \\
\hline 72 & & & $0.71 \pm 0.11$ & $0.79 \pm 0.08$ & $0.73 \pm 0.06$ & $0.90 \pm 0.08$ \\
\hline
\end{tabular}

Values are mean \pm s.e.m. for 6 (FSH, winter and summer), 13 (LH, winter) and 7 (LH, summer) samples per sow. Means in same row with different superscripts are different: ${ }^{\mathrm{a}} v s^{\mathrm{b}}, P<0 \cdot 10 ;^{\mathrm{c}} v s^{\mathrm{d}}, P<0 \cdot 05$. 

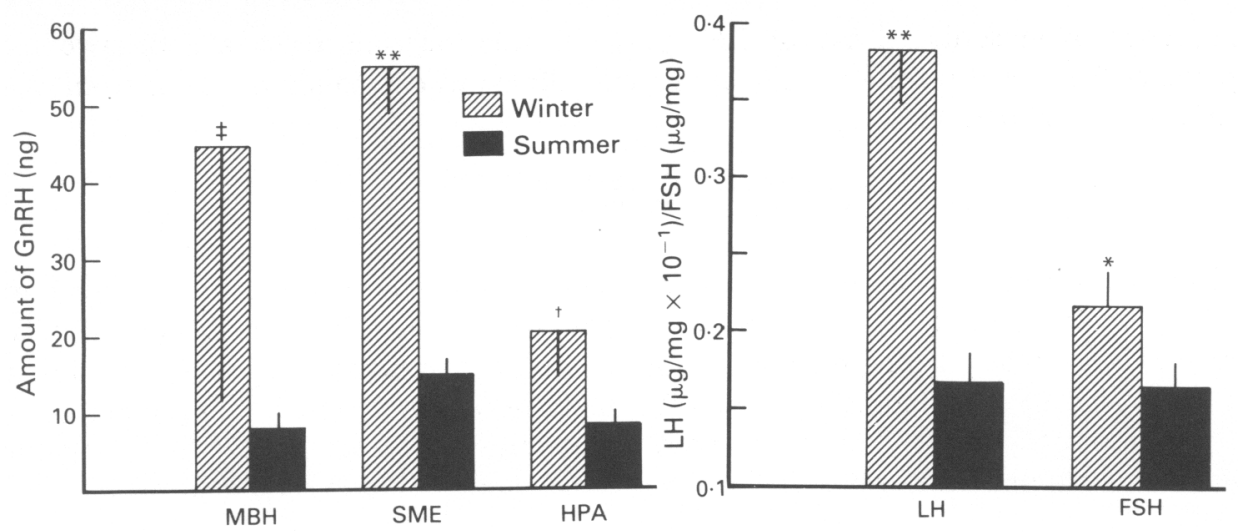

Fig. 1. Average amount of GnRH ( \pm s.e.m.) in medial basal hypothalamus (MBH), stalk median eminence (SME) and hypophysial portal area (HPA) and concentrations of LH and FSH ( \pm s.e.m.) in anterior pituitaries of sows weaned in winter and summer. $\dagger P<0 \cdot 12$; $\ddagger P<0 \cdot 10 ;{ }^{*} P<0.05 ;{ }^{* *} P<0.001$ compared with summer value.

Anterior pituitary gonadotrophin concentrations are depicted in Fig. 1 and values obtained at 0 and $72 \mathrm{~h}$ were not different within season and were pooled. Anterior pituitary weights were similar between sows weaned in summer $(279 \pm 14 \mathrm{mg})$ and in winter $(266 \pm 15 \mathrm{mg})$. Concentrations of LH $(P<0.001)$ and FSH $(P<0.05)$ in the anterior pituitary were greater in winter than in summer.

The number of small visible follicles at weaning $(0 \mathrm{~h})$ was greater in winter than in summer $(P<0.01$; Table 3 ), but values were similar at $72 \mathrm{~h}$ after weaning. An interaction of season $\times \mathrm{h}$ after weaning occurred because the number of small follicles decreased from 0 to $72 \mathrm{~h}$ after weaning in winter $(P<0.05)$ but not in summer. The number of follicles $>5 \mathrm{~mm}$ in diameter was similar at weaning, but at $72 \mathrm{~h}$ after weaning, the number of large follicles was greater $(P<0.01)$ in summer than in winter. Number of large follicles increased from 0 to $72 \mathrm{~h}$ in summer but not in winter (season $\times$ h interaction, $P<0.05$ ).

Table 3. Number of surface follicles in both ovaries in primiparous sows, weaned in winter or summer

\begin{tabular}{cccc}
\hline & & \multicolumn{2}{c}{ Season } \\
\cline { 3 - 4 } $\begin{array}{c}\text { Follicle } \\
\text { diam. }\end{array}$ & $\begin{array}{c}\text { Hours after } \\
\text { weaning }\end{array}$ & Winter & Summer \\
\hline \multirow{2}{*}{$<5 \mathrm{~mm}$} & 0 & $96 \cdot 8 \pm 8 \cdot 9^{\mathrm{a}}$ & $54 \cdot 0 \pm 14 \cdot 8^{\mathrm{b}}$ \\
& 72 & $36 \cdot 8 \pm 8 \cdot 1^{\mathrm{b}}$ & $40 \cdot 3 \pm 2 \cdot 3^{\mathrm{b}}$ \\
$>5 \mathrm{~mm}$ & 0 & $2 \cdot 8 \pm 1 \cdot 2^{\mathrm{a}}$ & $0 \pm 0 \pm 0^{\mathrm{a}}$ \\
& 72 & $6 \cdot 3 \pm 2 \cdot 0^{\mathrm{a}}$ & $16 \cdot 8 \pm 0 \cdot 3^{\mathrm{b}}$ \\
\hline
\end{tabular}

Values are mean \pm s.e.m. for $5(0 \mathrm{~h}$, winter and summer $), 6$ ( $72 \mathrm{~h}$, winter) and $4(72 \mathrm{~h}$, summer) sows.

Means in same row $(P<0.01)$ and column $(P<0.05)$ with different superscripts are different.

One sow in each season failed to exhibit oestrus and ovulation apparently did not occur because serum progesterone concentrations remained $<1.0 \mathrm{ng} / \mathrm{ml}$.

All sows that exhibited oestrus in winter and 4 of 8 sows that exhibited oestrus in summer had oestradiol profiles that were greater than basal values for $30-48 \mathrm{~h}$ before oestrus. Average concentrations of oestradiol in these sows are depicted in Fig. 2. Oestradiol concentrations were basal 


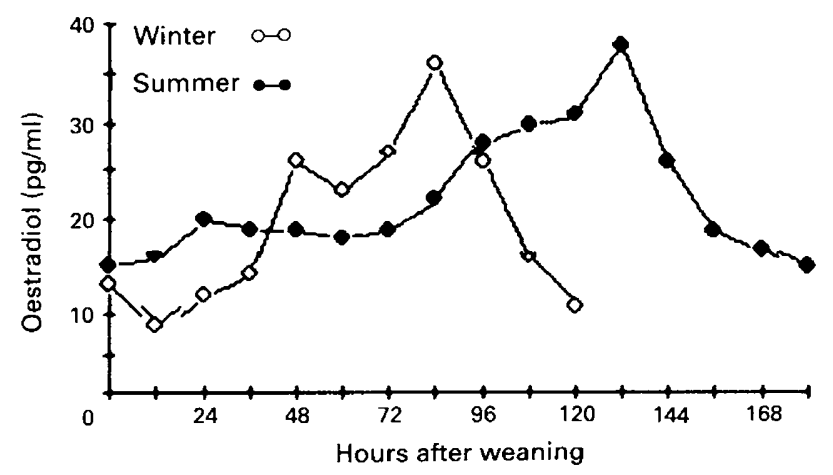

Fig. 2. Average serum oestradiol-17 $\beta$ concentrations for sows weaned in winter $(N=5)$ and summer $(\mathrm{N}=4)$ considered to have normal post-weaning oestradiol profiles. Standard errors ranged from 0.6 to $7 \cdot 7 \mathrm{pg} / \mathrm{ml}$.

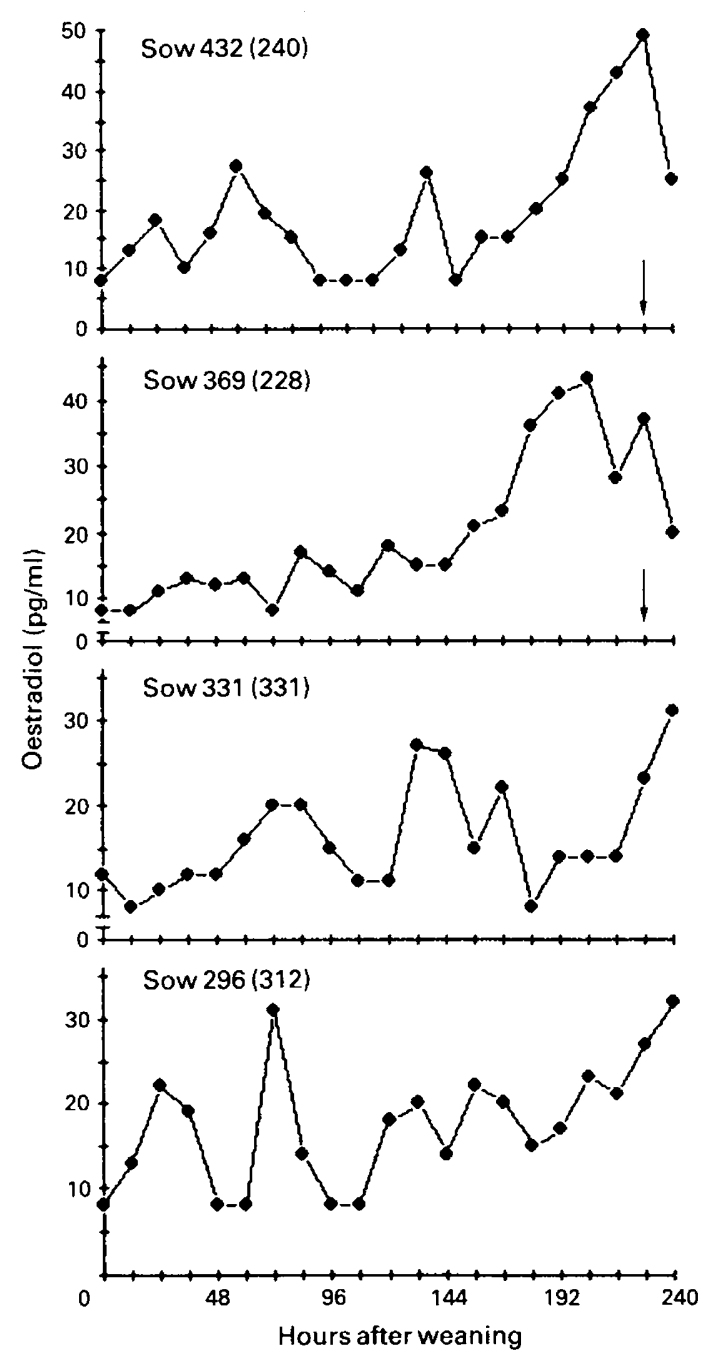

Fig. 3. Serum oestradiol profiles for 4 sows weaned during summer with remating intervals $>220 \mathrm{~h}$. Weaning to oestrus interval $(\mathrm{h})$ is in parentheses and arrows indicate onset of oestrus. 
from weaning until $48-72 \mathrm{~h}$ before oestrus, then increased to maximum concentrations of $35-40 \mathrm{pg} / \mathrm{ml}$. For sows with normal oestradiol profiles, the intervals (h) from peak oestradiol to oestrus $(15.5 \pm 5 \cdot 8$ vs $18.0 \pm 5 \cdot 2)$, peak oestradiol to peak LH $(16.8 \pm 4 \cdot 3$ vs $13.5 \pm 3.3)$ and oestrus to peak LH $(1.2 \pm 2 \cdot 6 v s-4.5 \pm 5 \cdot 8)$ did not differ between winter and summer.

Individual profiles of oestradiol secretion for sows weaned in summer and classified as having abnormal secretory patterns are depicted in Fig. 3. The pattern of oestradiol secretion after weaning was deemed abnormal, because transient surges of oestradiol occurred before the pro-oestrous increase. One sow (No. 318; data not shown) developed cystic ovaries sometime after $144 \mathrm{~h}$ because progesterone concentrations were $8-10 \mathrm{ng} / \mathrm{ml}$ for several days afterwards and a spike of oestradiol secretion $(168 \mathrm{pg} / \mathrm{ml})$ was detected $240 \mathrm{~h}$ after weaning.

\section{Discussion}

This study revealed that seasonal differences in duration of post-weaning anoestrus in primiparous sows were associated with seasonal differences in the activity of the hypothalamic-hypophysialovarian axis. A primary difference between sows that lactated in winter and summer was the 2-4-fold greater amounts of GnRH in the MBH, SME and HPA after weaning in the winter group. This was associated with a shorter period of anoestrus and with less variation in the weaning-tooestrus interval. Insufficient production of $\mathrm{GnRH}$ may then be a prime factor responsible for seasonal anoestrus. Hart, Squires, Imel \& Nett (1984) reported that seasonal anoestrus in the mare also was associated with lower amounts of $\mathrm{GnRH}$ in the hypothalamus and lower concentrations of $\mathrm{LH}$ in the anterior pituitary.

The lower amounts of GnRH within the hypothalamus of sows that lactated during summer was probably responsible for the lower amounts of $\mathrm{LH}$ found in the pituitaries and fewer small follicles on the ovaries of these sows at weaning. Sows that lactated during the summer may therefore have been in a deeper state of anoestrus at weaning, and the prolonged weaning-to-oestrus interval of these sows may reflect a slower response of the hypothalamus to removal of the inhibitory effects of suckling by the litter. Factors responsible for this delayed response by the hypothalamus are unclear and may involve higher brain centres because the ovary (Schilling \& Cerne, 1972; King, Williams \& Barker, 1982; Dial, Bevier, Hixon \& Gustafsson, 1984), anterior pituitary and hypothalamus (Cox, Esbenshade \& Britt, 1983; Dial et al., 1984) of chronically anoestrous sows are capable of responding to appropriate endocrine stimuli. Furthermore, Hurtgen \& Leman (1979) and Britt, Esbenshade \& Heller (1984) reported that exogenous stimulation (PMSG) at weaning hastened the onset of ovarian activity in primiparous sows weaned during summer.

The greater number of large follicles in sows killed $72 \mathrm{~h}$ after weaning (Table 3 ) along with the aberrant patterns of oestradiol secretion observed in 5 of 10 sows observed for signs of oestrus after weaning (Fig. 3) indicate that follicular growth occurred after weaning during summer. However, we suspect that these initial waves of follicular growth were not temporally related to the LH surge, because oestrus and ovulation occurred several days later. The hypothalamus of primiparous sows weaned during summer may be more sensitive to the negative feedback effects of oestradiol. Increased sensitivity to the negative feedback effects of oestradiol is putatively responsible for the low frequency of LH release and ovarian inactivity reported during seasonal (Legan, Karsch \& Foster, 1977) and post-partum (Wright, Geytenbeck, Clarke \& Findlay, 1981) anoestrus in ewes. Also, hypothalamic centres mediating the positive feedback effects of oestradiol may have been less responsive during summer. Positive feedback responses of $\mathrm{LH}$ to oestradiol increase as lactation progresses (Elsaesser \& Parvizi, 1980). Moreover, there appears to be a seasonal difference in the ability of oestradiol to induce ovulation in anoestrous gilts; responses are lowest during summer and early autumn and highest during winter (Paterson, 1982). 
The observation that content of GnRH in the hypothalamus and concentration of $\mathrm{LH}$ in the anterior pituitary were similar at 0 and $72 \mathrm{~h}$ after weaning in winter was unexpected, because Cox \& Britt (1982c) reported that hypothalamic GnRH and anterior pituitary levels of $\mathrm{LH}$ increased from 0 to $60 \mathrm{~h}$ after weaning. There are several possible reasons for this discrepancy. In the initial studies, animals were not killed until the 5 th or 6 th week of lactation and litter sizes in those studies were only $60-70 \%$ as large as in the present study. Moreover, in the studies of Cox \& Britt (1982c), hypothalamic GnRH and anterior pituitary LH were temporally related to changes in ovarian weight and follicle number after weaning; however, in the present study, the numbers of large follicles in sows killed during winter were similar at 0 and $72 \mathrm{~h}$ after weaning. Therefore, the ability of the hypothalamus to respond to weaning by increasing synthesis of GnRH and temporal relationships between synthesis and release of $\mathrm{GnRH}$ and $\mathrm{LH}$ and follicular growth may have differed considerably between studies.

The concentrations of $\mathrm{LH}$ and FSH in serum immediately after weaning also differed between winter and summer (Table 2). Although serum concentrations of LH at weaning were greater in winter than summer, frequency of episodic release of $\mathrm{LH}$ after weaning was similar; however, our sampling interval may not have been of sufficient length to detect differences. The frequency of release of $\mathrm{LH}$ before weaning may be a better predictor of the weaning-to-oestrus interval, because frequency of $\mathrm{LH}$ release before weaning was lower in sows that exhibited longer periods of anoestrus after weaning; however, frequency of $\mathrm{LH}$ release after weaning was not related to the duration of post-weaning anoestrus (Armstrong \& Britt, 1984; Shaw \& Foxcroft, 1985).

The results of the present experiment confirm the observation by Stevenson et al. (1981) that LH and FSH secretion are controlled by different mechanisms during and after lactation in pigs. In contrast to LH, serum FSH concentrations at weaning were greater in summer than winter (Table 2), apparently because greater amounts of FSH were being released from anterior pituitaries of sows weaned during summer (Fig. 1). Different mechanisms mediating LH and FSH secretion apparently persist after weaning, because concentrations of LH and FSH in anterior pituitaries do not change in parallel after weaning (Crighton \& Lamming, 1969; Cox \& Britt, 1982c).

We suggest that seasonal differences in amount of follicular development observed at weaning may account for increased FSH release in sows weaned in summer. We speculate that during summer, when follicular development was lower, there was a lower output of inhibin by the ovary. Inhibin is found in highest concentrations in small $(<5 \mathrm{~mm})$ follicles and inhibits release of FSH from the anterior pituitary (Franchimont et al., 1981). In the present study, the number of small follicles was lower in summer than winter (Table 3) and the higher secretion of FSH after weaning during summer may have been inversely related to amount of inhibin being secreted. Cox \& Britt (1983) have reported that cauterization of ovarian follicles $>3 \mathrm{~mm}$ in diameter during lactation resulted in elevated serum FSH values $24-36 \mathrm{~h}$ later, even though concentrations of oestradiol-17 $\beta$ were similar between cauterized sows and sham-operated controls (N. M. Cox, J. D. Armstrong \& J. H. Britt, unpublished).

Although specific cause-effect relationships responsible for delayed remating during summer were not evaluated in this study, our data indicate that nutrition during lactation may be involved. Sows that lactated during summer consumed less food and subsequently mobilized more of their body reserves than did sows in winter (Table 1). Energy restriction during lactation results in greater weight and backfat loss during lactation and prolonged remating intervals in primiparous sows (Reese et al., 1982; King \& Williams, 1984a, b). In addition, weight (Lengele, 1978) and heartgirth (Miyajama, Shiiba, Kohno \& Inagaki, 1979; Armstrong \& Britt, 1984) changes during lactation are inversely related to interval from weaning to oestrus.

In conclusion, seasonal differences in remating intervals of primiparous sows are apparently due to altered activity of the hypothalamus. Inadequate stimulation of the anterior pituitary by GnRH resulted in lower synthesis and secretion of $\mathrm{LH}$, decreased follicular growth and longer intervals from weaning to oestrus in sows weaned in summer than in winter. Aberrations of the hypothalamus and (or) higher brain centres of primiparous sows weaned during summer persisted 
after weaning, but endocrine mechanisms responsible for this lesion cannot be determined. However, lower food intake during lactations that occur during summer may predispose the endocrine system to those aberrations.

Paper No. 10171 of the Journal series of the North Carolina Agricultural Research Service, Raleigh, NC 27695-7601. The use of trade names in this publication does not imply endorsement by the North Carolina Agricultural Research Service of the product named, or criticism of similar ones not mentioned. Supported in part by grant 82-CRSR-2-1069 from USDA.

\section{References}

Armstrong, J.D. \& Britt, J.H. (1984) Effect of energy restriction during lactation on reproductive performance, energy metabolites and endocrine changes in primiparous sows. Proc. 10th Int. Cong. Anim. Reprod, \& A. I., Urbana II, 157.

Armstrong, J.D. \& Britt, J.H. (1985) Pulsatile administration of gonadotropin-releasing hormone to anestrous sows: endocrine differences associated with GnRH-induced and spontaneous estrus. Biol. Reprod. 33, 375-380.

Aumaitre, A., Dagorn, J., Legault, C. \& Le Denmat, M. (1976) Influence of farm management and breed type on sow's conception-weaning interval and productivity in France. Livestock Prod. Sci. 3, 75-83.

Britt, J.H., Szarek, V.E. \& Levis, D.G. (1983) Characterization of summer infertility of sows in large confinement units. Theriogenology 20, 133-140.

Britt, J.H., Esbenshade, K.L. \& Heller, K. (1984) Response of seasonally acyclic gilts and weaned primiparous sows to pregnant mare's gonadotropin (PMSG) and Regumate. J. Anim. Sci. 59, Suppl. 1, 20-21, Abstr.

Cox, N.M. \& Britt, J.H. (1982a) Association between patterns of serum LH and changes in $E_{2}$ during the weaning-to-estrus period in sows. J. Anim. Sci. 55, Suppl. 1, 346, Abstr.

Cox, N.M. \& Britt, J.H. (1982b) Pulsatile administration of GnRH to lactating sows: endocrine changes associated with induction of fertile estrus. Biol. Reprod. 27, 1126-1137.

Cox, N.M. \& Britt, J.H. (1982c) Relationships between endogenous $\mathrm{GnRH}$, gonadotropins and follicular development after weaning in sows. Biol. Reprod. 27, $70-78$.

Cox, N.M. \& Britt, J.H. (1982d) Effects of estradiol on hypothalamic GnRH and pituitary and serum $\mathrm{LH}$ and FSH in ovariectomized pigs. J. Anim. Sci. 55, 901-908.

Cox, N.M. \& Britt, J.H. (1983) Postweaning estrus in sows is not prevented by electrocauterization of ovarian follicles before weaning. J. Anim. Sci. 57, Suppl. 1, 34, Abstr.

Cox, N.M., Esbenshade, K.L. \& Britt, J.H. (1983) Treatment of long-term anestrous sows with estradiol benzoate: response of serum $\mathrm{LH}$ and occurrence of estrus. Theriogenology 20,499-507.

Crighton, D.B. \& Lamming, G.E. (1969) The lactational anoestrus of the sow: the status of the anterior pituitary-ovarian system during lactation and after weaning. J. Endocr. 43, 507-518.
Dial, G.D., Bevier, G.W., Hixon, J.E. \& Gustafsson, B.K. (1984) Endocrine pathogenesis of postweaning anestrus in swine: response of the persistently anestrous sow to hormonal stimuli. Am. J. vet. Res. 45, 1737-1742.

Edwards, S. \& Foxcroft, G.R. (1983) Endocrine changes in sows weaned at two stages of lactation. J. Reprod. Fert. 67, 161-172.

Elsaesser, F. \& Parvizi, N. (1980) Partial recovery of the stimulatory oestrogen feedback action on $\mathrm{LH}$ release during late lactation in the pig. J. Reprod. Fert. 59, 63-67.

Esbenshade, K.L. \& Britt, J.H. (1985) Active immunization of gilts against gonadotropin-releasing hormone: effects on secretion of gonadotropins, reproductive function and responses to agonists of gonadotropinreleasing hormone. Biol. Reprod. 33, 569-577.

Estes, K.K., Padmanabhan, V. \& Convey, E.M. (1977) Localization of gonadotropin releasing hormone (GnRH) within the bovine hypothalamus. Biol. Reprod. 17, 706-711.

Franchimont, P., Henderson, K., Verhoeven, G., HazeeHagelstein, M.-T., Charlet-Renard, C., DeMoulin, A., Bourguignon, J.-P. \& LeComte-Yerna, M.J. (1981) Inhibin: mechanisms of action and secretion. In Intragonadal Regulation of Reproduction, pp. 166-191. Eds P. Franchimont \& C. P. Channing. Academic Press, New York.

Gill, J.L. \& Hafs, H.D. (1971) Analysis of repeated measurements of animals. J. Anim. Sci. 33, 331-336.

Guthrie, H.D. \& Bolt, D.J. (1983) Changes in plasma estrogen, luteinizing hormone, follicle-stimulating hormone and 13,14-dihydro-15-keto-prostaglandin $\mathrm{F}_{2} \alpha$ during blockade of luteolysis in pigs after human chorionic gonadotropin treatment. J. Anim. Sci. 57, 993-1000.

Hart, P.J., Squires, E.L., Imel, K.J. \& Nett, T.M. (1984) Seasonal variation in hypothalamic content of gonadotropin releasing hormone $(\mathrm{GnRH})$, pituitary receptors for $\mathrm{GnRH}$, and pituitary content of luteinizing hormone and follicle-stimulating hormone in the mare. Biol. Reprod. 30, 1055-1062.

Hurtgen, J. \& Leman, A.D. (1979) Use of PMSG in the prevention of seasonal post-weaning anestrus of sows. Theriogenology 12, 207-214.

Hurtgen, J., Leman, A.D. \& Crabo, B.O. (1980) Seasonal influence on estrus activity in sows and gilts. J. Am. vet. Med. Assoc. 176, 119-123.

King, R.H. \& Williams, I.H. (1984a) The effect of nutrition on the reproductive performance of first-litter 
sows. 1. Feeding level during lactation, and between weaning and mating. Anim. Prod. 38, 241-247.

King, R.H. \& Williams, I.H. (1984b) The effect of nutrition on the reproductive performance of first-litter sows. 2. Protein and energy intakes during lactation. Anim. Prod. 38, 249-256.

King, R.H., Williams, L.H. \& Barker, I. (1982) Induction of oestrus in anestrus first litter sows with pregnant mare's serum gonadotropin. Anim. Reprod. Sci. 5, 41-45.

Koch, Y., Wilchek, M., Fridkim, M., Chobsieng, P., Zor, U. \& Linder, H.R. (1973) Production and characterization of an antiserum to synthetic gonadotropinreleasing hormone. Biochem. Biophys. Res. Commun. $55,616-622$.

Legan, S.L., Karsch, F.J. \& Foster, D.L. (1977) The endocrine control of seasonal reproductive function in the ewe: a marked change in response to the negative feedback action of estradiol on luteinizing hormone secretion. Endocrinology 101, 818-824.

Lengele, L. (1978) Fertility and variation in weight in the primiparous sow. Revue de l'Agriculture 31, 105-111.

Mason, N.R. \& March, R. (1975) Cyclic AMP in the rat ovary: effect of exogenous LH secretion. Endocr. Res. Commun. 21, 357-361.

Miyajima, M., Shiiba, J., Kohno, T. \& Inagaki, J. (1979) The effect of various factors on the occurrence of postpartum oestrus in pigs. Jap. J. Swine Husb. Res. 16, 45-55.

Nett, T.M., Akbar, A.M., Niswender, G.D., Hedlund, M.T. \& White, W.F. (1973) A radioimmunoassay for gonadotropin-releasing hormone $(\mathrm{GnRH})$ in serum. J. clin. Endocr. Metab. 36, 880-885.

NRC (1979) Nutrient Requirements of Pigs, 8th revised edn. National Academy of Science, National Research Council, Washington, D.C.
Paterson, A.M. (1982) The controlled induction of puberty. In Control of Pig Reproduction, pp. 139-159. Eds D. J. A. Cole \& G. R. Foxcroft. Butterworths, London.

Reese, D.E., Moser, B.D., Peo, E.R., Jr, Lewis, A.J., Zimmerman, D.R., Kinder, J.E. \& Stroup, W.W. (1982) Influence of energy intake during lactation on the interval from weaning to first estrus in sows. $J$. Anim. Sci. 55, 590-598.

SAS (1982) SAS User's Guide. Statistical Analysis System Institute, Inc., Cary, North Carolina.

Schilling, E. \& Cerne, F. (1972) Induction and synchronization of oestrus in prepuberal gilts and anoestrous sows by a PMS/HCG compound. Vet. Rec. 91, 471-474.

Shaw, H.J. \& Foxcroft, G.R. (1985) Relationships between LH, FSH and prolactin and reproductive activity in the weaned sow. J. Reprod. Fert. 75, 17-28.

Sokal, R.R. \& Rohlf, F.J. (1969) Biometry. W. H. Freeman and Company, San Francisco, California.

Steel, R.G.D. \& Torrie, J.H. (1980) Principles and Procedures of Statistics: A Biometrical Approach, 2nd edn. McGraw-Hill Book Company, New York.

Stevenson, J.S. \& Britt, J.H. (1979) Relationships among luteinizing hormone, estradiol, progesterone, glucocorticoids, milk yield, body weight and postpartum ovarian activity in Holstein cows. J. Anim. Sci. 48, $570-577$.

Stevenson, J.S., Cox, N.M. \& Britt, J.H. (1981) Roile of the ovary in controlling luteinizing hormone, follicle stimulating hormone, and prolactin secretion during and after lactation in pigs. Biol. Reprod. 24, 341-353.

Wright, P.J., Geytenbeck, P.E., Clarke, I.J. \& Findlay, J.K. (1981) Evidence for a change in oestradial negative feedback and $\mathrm{LH}$ pulse frequency in post-partum ewes. J. Reprod. Fert. 61, 97-102.

Received 4 November 1985 